\title{
深基坑公路施工技术探讨
}

吴光星

DOI:10.32629/btr.v2i7.2323

[摘 要] 基于新时代背景下,随着我国公路工程的发展以及建设规模的持续扩张,关于公路施工质量有了新目标与新要求。此 种形势下,传统施工技术的许多弱点暴露无遗,已经难以保证公路工程施工质。深基坑施工技术凭借着便捷性、成本低、效率 高等优势,在公路施工中得以普遍使用,而且能够有效保证公路工程的整体施工质量。

[关键词] 公路工程; 深基坑；施工技术

随着我国交通事业的发展, 公路工程建设规模越来越大, 其中施工技术问题受到了社会各界的重点关注。对于传统施 工技术而言, 必须要进行完善与创新, 从而才可以有效保障 公路工程的整体质量与安全性。而深基坑施工技术作为科学 技术发展的必然产物, 在进行公路工程施工时使用深基坑技 术, 能够提高施工效率、控制成本, 提高施工质量, 但是此项技 术仍然处在摸索阶段, 在实践之中需要不断的进行完善。基于 此, 研究深基坑公路工程施工技术具有现实意义。

\section{1 深基坑施工技术的特点与支护类型}

1. 1 施工技术的特点

从公路工程施工方面分析, 基坑围护结构具有风险性, 而选用深基坑施工技术可以有效保证深基坑的施工效率与 质量。

1.1. 1 使用深基坑施工技术, 能够为公路工程结构创造 一个良好的作业面, 在一定程度上控制对工程管线等造成的 影响, 属于一项经济性施工技术。

1.1.2关于深基坑施工技术的有效使用, 必须具备多方 面知识, 比如土力学中的变形、建筑结构等, 应该进行综合性 分析与考量, 由此可知深基坑施工技术是十分的复杂。

\section{2 深基坑支护的类型}

站在深基坑支护类型角度分析, 其突出性特点就是多样 性, 基本分成土钉支护、针杆支护以及内支撑支护等 ${ }^{[1]}$ 。其 中土钉支护指的是选用许多土钉, 由其组建成为牢固、可靠 的土钉构件, 然后完成对原位土体与凝土面的有效加固, 产 生密集的土钉, 由此就可以提高结构自身的安全性与稳定 性; 而内支撑支护包含了钢结构与混凝土结构, 两者之间存 在着许多差异性, 最为明显的就是结构与变形的不同, 在内 支撑支护时间使用过程之中必须要结合现实状况准确选择 具体的内支撑支护类型, 例如关于刚度要求十分严格, 就需 要使用混凝土结构。而针杆支护需要与土钉支护或者是内支 撑支护进行搭配使用, 但是对环境有着特殊要求, 例如坑外 存在积水, 则要选择土钉支护与支护错形式。从本质上分析, 内支撑与针杆直接决定着深基坑的安全性、稳定性 ${ }^{[2]}$ 。此外, 边坡开挖技术作为公路工程项目中最为普遍的一项施工技 术, 为了能够确保基坑开挖时不会对地下管线等带来不利影 响, 通常情况下需要于地势相对比较宽阔的位置展开施工。

\section{2 公路工程中深基坑施工技术的应用}

2.1 施工之前钢板支护

钢板支护的根本性目标是进行结构支撑, 从而为深基坑 施工技术的有效使用创造有利条件。详细的讲就是：第一, 选择测量工具完成承台面积与钢板桩的准确测量, 而且得出 承台尺寸后需要增加 1.5 厘米, 这样就能够使承台测量尺寸 变得更加的准确 ${ }^{[3]}$ 。此外, 也要完成地面标高的准确测量, 这 样才能够为施工技术人员提供真实、有效的数据信息。第二, 以现实状况作为依据, 严格控制钢板桩的尺寸, 一般需要保 证在 2 米之内。若是数据发生了偏差, 那么施工技术人员就必 须有效调整。

\section{2 标高处进行深基坑标识}

根据公路工程项目的具体标高位置, 对深基坑的标识进 行科学化、合理化设计, 这样才能够确保公路工程施工的可 靠性与安全性, 提高公路工程施工质量。一般情况下, 在进行 公路工程项目施工时, 选择深基坑施工技术的根本性前提就 是必须对深基坑底部进行填平处理, 而在进行此项作业前, 一定要完成高度标识工作, 同时认真对其检验, 当确认没有 偏差之后, 还需要及时的把钢板桩于标识之中拔出。此外, 还应该对公路工程项目展开严格的系统性检查, 以保证公路 工程的整体施工质量。

\section{3 深基坑的插桩}

在进行插桩作业时, 施工技术人员必须要严格控制板桩 的具体长度, 在插入后能够露出地面。对于漏出地面的长度, 通常情况下需要控制 30 米之内。与此同时, 为了能够保证板 桩可以一次到位, 就一定要在前期完成导向架与板桩垂度的 有效测量, 主要使用全站仪设施进行准确测量, 这样能够提 高测量数据信息的有效性。完成打桩作业之后, 就要及时开 挖公路工程 ${ }^{[4]}$ 。而为了能够提高公路工程开挖的施工效率, 以机械施工为主, 针对机械设施不能进行作业的位置, 则选 择人工开挖方式, 由此 “机械 $+人$ 工 的形式能够使开挖工程 更为全面与彻底。除此之外, 在基坑开挖过程之中会形成许 多渣土, 为了能够保证施工质量与施工进度, 必须把渣土运 输至指定的区域, 然后进行统一性处理。

2. 4 开挖内支撑安装

内支撑作为基坑支护结构的核心之一, 发挥着关键性作 
用。所以公路工程开挖时遇到了内支撑, 作为施工技术人员 必须要选择适当技术方法完成开挖作业。具体如下: 在工程 开挖时, 若是遇到了第一道内支撑, 就必须要立即停止施工, 需要在水平方向进行支撑, 然后及时安装支垫钢板, 从而才 可以继续开挖; 若是遇到了第二道内支撑, 应该使用上述方 法, 同时严格检查支点与开挖点情况, 一定要确保内支撑处 在顶紧状态之下。此外, 基坑开挖工程施工结束之后, 应该科 学处理板桩与桩头, 这样能够为深基坑施工与公路工程质量 创造有利条件。

\section{3 公路工程中深基坑施工技术需要注意的问题}

3. 1 降水问题

降水是公路公衡深基坑施工必须注意的一项问题, 其中 降水速度与降水量直接影响着工程的质量。为了能够防止发 生公路工程质量问题, 就必须要对降水问题进行严格控制, 实时监测管线与地表等有关情况, 结合监测具体结果科学控 制施工降水量, 这样就能够为公路工程的安全施工创造有利 保障。

\section{2 用水管问题}

事实上,公路工程深基坑开挖势必会对管线等造成影响, 而水管是居民生活用水的基本保障, 如果水管发生了问题, 那么不仅会影响居民的生活, 也会对公路工程的施工质量造 成负面影响 ${ }^{[5]}$ 。基于此, 必须要严格监测水管, 若是发现水管 存在渗漏等问题, 就一定要及时进行处理与解决。

\section{3 土方开挖问题}

土方开挖作为深基坑施工的核心内容之一, 关系着公路 工程项目的总体施工质量。所以为了能够提高公路工程的施 工质量与安全性, 就必须要高度重视土方开挖问题, 比如土 方开挖长度、选择的开挖方法等, 应该根据公路工程实际需 要进行确定。其中土方开挖长度, 需要结合深基坑深度与坡
度情况科学设计, 关于开挖方法的选择应该进行分层开挖, 一般情况下不选择掏底开挖或者是超挖。为了能够严格把 控深基坑变形问题, 要保证深基坑的深度满足设计值要求, 同时完成垫层混凝土浇筑工作, 从而切实保证深基坑施工 质量。

\section{4 结束语}

在公路工程中有效使用深基坑施工技术, 能够提高公路 工程的施工质量, 加强公路的可靠性与安全性, 也能够在一 定程度上减小对工程区域管线等方面的影响, 从而为交通事 业创造更多的经济效益与社会效益。然而因为深基坑施工技 术仍然处在摸索阶段, 在实践应用时具有风险性, 所以作为 施工技术人员必须要根据现实情况, 科学、有效应用深基坑 施工技术, 充分发挥其作用与价值。

\section{[参考文献]}

[1]张书玉,刘波,席培胜.某紧邻高速公路偏压深基坑施工 方案设计与监测分析 [J].安徽建筑大学学报,2014,22(4):54-59.

[2]郭虎.深基坑土钉支护技术在公路施工中的应用 [J]. 山西建筑,2017,43(06):81-82.

[3] 谢强,王晶晶,顾小辉, 等. 临近既有公路深基坑边坡的 稳定性分析与处置措施研究 [J].公路交通科技(应用技术 版),2017,13(12):125-128.

[4]赵奇志.公路深基坑施工技术及质量安全控制的探析 [J].工程建设与设计,2018,(16):44-45.

[5]王树民.公路建设中深基坑的施工技术研究[J].黑龙 江科技信息,2015,(26):211.

\section{作者简介:}

吴光星(1986--), 男, 江苏徐州人,汉族,专科学历, 身份证 号：320322198611183850,研究方向：公路工程施工,从事工 作,公路工程师。 